\title{
Shared Neurodevelopmental Perturbations Can Lead to Intellectual Disability in Individuals with Distinct Rare Chromosome Duplications
}

\author{
Thiago Corrêa ${ }^{1} \mathbb{D}$, Cíntia B. Santos-Rebouças ${ }^{2}$, Maytza Mayndra ${ }^{3}$, Albert Schinzel $^{4}$ and Mariluce Riegel ${ }^{1,5, * \mathbb{D}}$ \\ 1 Department of Genetics, Institute of Biosciences, Federal University of Rio Grande do Sul UFRGS, \\ Porto Alegre 91501-970, Brazil; thiagocorrea252@gmail.com \\ 2 Department of Genetics, Institute of Biology Roberto Alcantara Gomes, State University of Rio de Janeiro, \\ Rio de Janeiro 20511-010, Brazil; cbs@alternex.com.br \\ 3 Children's Hospital Jeser Amarante Faria, Joinville 89204-310, Brazil; maytzac@gmail.com \\ 4 Institute of Medical Genetics, University of Zurich, 8952 Schlieren, Switzerland; schinzel@medgen.uzh.ch \\ 5 Medical Genetics Service, Hospital de Clínicas de Porto Alegre, Porto Alegre 90035-903, Brazil \\ * Correspondence: mriegel@hcpa.edu.br
}

\section{check for}

updates

Citation: Corrêa, T.;

Santos-Rebouças, C.B.; Mayndra, M.;

Schinzel, A.; Riegel, M. Shared

Neurodevelopmental Perturbations

Can Lead to Intellectual Disability in

Individuals with Distinct Rare

Chromosome Duplications. Genes

2021, 12, 632. https://doi.org/

10.3390/genes12050632

Academic Editors: Orazio Palumbo and Paolo Cinelli

Received: 1 March 2021

Accepted: 16 April 2021

Published: 23 April 2021

Publisher's Note: MDPI stays neutral with regard to jurisdictional claims in published maps and institutional affiliations.

Copyright: (c) 2021 by the authors. Licensee MDPI, Basel, Switzerland. This article is an open access article distributed under the terms and conditions of the Creative Commons Attribution (CC BY) license (https:// creativecommons.org/licenses/by/ $4.0 /)$.

\begin{abstract}
Chromosomal duplications are associated with a large group of human diseases that arise mainly from dosage imbalance of genes within the rearrangements. Phenotypes range widely but are often associated with global development delay, intellectual disability, autism spectrum disorders, and multiple congenital abnormalities. How different contiguous genes from a duplicated genomic region interact and dynamically affect the expression of each other remains unclear in most cases. Here, we report a genomic comparative delineation of genes located in duplicated chromosomal regions 8q24.13q24.3, 18p11.32p11.21, and Xq22.3q27.2 in three patients followed up at our genetics service who has the intellectual disability (ID) as a common phenotype. We integrated several genomic data levels by identification of gene content within the duplications, protein-protein interactions, and functional analysis on specific tissues. We found functional relationships among genes from three different duplicated chromosomal regions, reflecting interactions of protein-coding genes and their involvement in common cellular subnetworks. Furthermore, the sharing of common significant biological processes associated with ID has been demonstrated between proteins from the different chromosomal regions. Finally, we elaborated a shared model of pathways directly or indirectly related to the central nervous system (CNS), which could perturb cognitive function and lead to ID in the three duplication conditions.
\end{abstract}

Keywords: duplication syndromes; intellectual disability; axon guidance; PPI-network

\section{Introduction}

Chromosomal duplication syndromes are caused by intrachromosomal rearrangements (due to genomic instability) and may result in overexpression of dosage-sensitive genes within the rearrangement and gene interruption or gene fusion at the breakpoint junctions [1,2]. As a consequence, chromosomal duplications can affect multiple functional proteins that need to be effective in terms of quantity, location, and time of activity. The consequence of these alterations can lead to damage in brain development and/or cognitive functioning [3,4]. Moreover, imbalances of proteins that compose multiprotein complexes may be extremely deleterious, when stochiometric changes in subunits affect biological processes [2,5]. Finally, the perturbation of hub-genes may also alter the expression and function of other sets of proteins, or even, produce aggregation of proteins that lead to cellular toxicity $[2,6]$.

Chromosomal duplications have a prevalence of $\sim 0.7 / 10.000$ births and are commonly associated with syndromic forms of Intellectual Disability (ID), a heterogeneous condition with a worldwide prevalence of $1 \%[4,7]$ that impairs intellectual functioning and adaptive 
behavior, manifesting before adulthood [8]. Usually, duplication syndromes are identified by Chromosomal Microarray Analysis (CMA), considered as the first-tier test that offers $15-20 \%$ of diagnostic rate for individuals with unexplained global developmental delay/ID and/or congenital anomalies [9].

Neurological processes are tightly regulated during the development and throughout the individual's life in a manner that any change can have deleterious effects on cognitive function [10]. Many cellular processes are affected in ID, including neurogenesis, neuronal migration to axon guidance, synaptic plasticity, dendritic arborization, and regulation of transcription and translation. These bioprocesses can converge on similar and connected pathways, involving common phenotypic manifestations $[4,10,11]$. Pathophysiology causing ID comprises proteins that emerge in pathways and cellular networks involving several biological functions that occur through interactions represented by the human interactome $[4,12]$. Moreover, chromosomal rearrangements may include regions significantly enriched for genes involved in brain development that can generate multiple pathogenic mechanisms [2].

Herein we determined whether genes located in duplicated regions in three patients followed up at our genetics service with rare but relevant regions (8q24.13q24.3, 18p11.32p11.21, and Xq22.3q27.2) are involved in shared central molecular pathways associated with genes related with ID. The 8q24.13q24.3 duplication identified is a rare chromosomal rearrangement associated with dysmorphic features, growth delay, and ID [13-16]. Moreover, variable levels of ID and cerebellum hypoplasia were described in patients with 18p11 duplications, however, few cases of pure duplications in this region have been reported with similar rearrangements so far [17-21]. Duplication at Xq22.3q27.2 is a condition with region enriched in genes related to neurological function involving many cases of ID, behavioral problems, holoprosencephaly, and cerebellar vermis hypoplasia [22-26]. Therefore, we integrated several levels of data by identification of gene content, protein-protein interactions, and functional analysis on specific tissues to suggest a model with common or related pathways to the central nervous system (CNS) functions in individuals affected by these duplication syndromes.

\section{Materials and Methods}

\subsection{Chromosomal Microarray Analysis (CMA)}

Three patients with ID were followed in the Medical Genetics Service-HCPA. The duplications were mapped by CMA using a 60-mer oligonucleotide-based microarray with a theoretical resolution of $40 \mathrm{~kb}(8 \times 60 \mathrm{~K}$, Agilent Technologies Inc., Santa Clara, CA, USA). The labeling and hybridization were performed following the protocols provided by Agilent, 2011. The arrays were analyzed using a microarray scanner (G2600D) and the Feature Extraction software (version 9.5.1, both from Agilent Technologies). UCSC Genome Browser on Human Feb. 2009 (GRCh37/hg19) was employed to identify all protein-coding genes from duplicated regions. The complete list of protein-coding genes can be seen in Supplementary Table S1.

\subsection{Interactome Construction and the Expanded Duplication Syndromes Interactome (eDSi)}

The human interactome was generated using the Human Integrated Protein-Protein Interaction Reference (HIPPIE) database (version 2.2) [27]. We filtered in the interactions with confidence score $>0.4$ and limited our analysis to the largest connected component, containing 16,108 nodes and 256,552 links/edges. Next, we extracted only protein-protein interactions from the three selected duplicated regions (Supplementary Table S2) and selected their first neighbor to expand and generate the eDSi. Cytoscape V.3.7.0. software [28] was used for visualization, and calculations of centrality parameters of the networks.

\subsection{Functional Modules Detection and Enrichment Analysis}

The HumanBase database integrates functional networks in tissues, gene expression, and disease associations. Evidence is provided by a massive set of experiments containing more 
than 14,000 publications and 144 tissue- and cell lineage-specific functional contexts [29,30]. We extracted significant biological processes in the eDSi, by using the detection of functional modules tool in specific tissues available in the HumanBase [31]. This tool allows the detection of tissue-specific functional modules, comprising related genes located in clusters that share local network neighborhood. The method uses k-nearest-neighbor (SKNN) and the Louvain community-finding algorithm to cluster the genes list into distinct modules of tightly connected genes [31]. q value was calculated using one-sided Fisher's exact tests and Benjamini-Hochberg corrections to correct for multiple tests and only values $<0.05$ were considered (Supplementary Table S3). Moreover, we used the webserver Enrichr [32] to identify significant pathways involved with neuronal functions in genes from the tissuespecific network. The gene-set libraries used were BioCarta, BioPlanet, Elsevier Pathway Collection, Kegg, Reactome, Panther, and WikiPathways. We considered only bioprocesses with a $p$-value $<0.05$.

\subsection{Prioritization of Candidate Genes}

To prioritize candidate genes associated with ID, we used a list of known ID-genes (Supplementary Table S4), available at http:/ / www.disgenet.org/ (accessed on 6 January 2020). DisGeNET is a platform that integrates data from UNIPROT, CGI, ClinGen, Genomics England, CTD (human subset), PsyGeNET, and Orphanet on human gene-disease associations [33]. We used a query list of ID-genes to expand the selection of nodes, using network propagation through the Diffusion algorithm (V. 1.6.1) [34]. Network propagation can estimate the distance between different sets of proteins, and identify a subnetwork with nodes closely related to each other [34]. The proximity among candidate genes and query ID-genes in the eDSi was measured using 302 as a maximum diffusion rank (highest allowed value). The complete list of prioritized genes is shown in Supplementary Table S5.

\subsection{Functional Tissue-Specific Data}

We used the list of the prioritized genes (Supplementary Table S5) to identify gene expression in tissues and construct a gene-disease association network in the HumanBase [29,30]. Moreover, a tissue-specific network with 18 genes highly expressed in the CNS was generated using data from co-expression, protein interaction, TF binding, microRNA targets, and perturbations. We prioritized the most expressed genes in the CNS, or genes previously reported in the literature involving ID in individuals with duplication regions. The parameters used to generate the network were a confidence $>0.10$ and a value of 15 for the maximum number of genes.

\section{Results}

\subsection{Identification of Rare Chromosome Duplications}

Chromosome duplications were mapped using the samples of three patients with ID using hg / 19 reference: 8q24.13q24.3 (Chr8:126,397,316-143,577,971); dup18p11.32p11.21 (Chr18:14,316-14,773,575); and dupXq22.3q27.2 (Chrx:106,283,188-140,340,737). The summary of CMA and clinical findings from the three patients with chromosomal duplications can be seen in Supplementary S1 and Table 1, respectively.

\subsection{DSi Proteins Tend to Have High Values of Betweenness}

The human interactome provided a network-based framework to investigate proteinprotein interactions between DSi-proteins (Figure 1a). The extraction of protein-coding genes from the duplicated regions and their first neighbor resulted in a DSi composed of 3016 nodes/proteins and 4330 links/interactions (Figure 1b). DSi included 89 proteins from duplicated regions and 65 ID-genes. Four DSi-proteins (LAMA1, STAG2, NKAP, and ALG13) were also found among the ID-genes list [35]. 
Table 1. Summary of the CMA and clinical findings from the 3 patient with chromosomal duplications.

\begin{tabular}{cccc}
\hline Patient & $\mathbf{1}$ & $\mathbf{2}$ & $\mathbf{3}$ \\
\hline Sex & $\mathbf{F}$ & $\mathbf{M}$ & $\mathbf{F}$ \\
\hline Age (years) & 8 & 12 & 7 \\
\hline Band location (duplicated) & Chr8 (q24.21-q24.3) & Chr18 (p11.32-p11.21) & ChrX (q22.3-q27.1) \\
\hline $\begin{array}{c}\text { CMA } \\
\text { Deletion size (pb) }\end{array}$ & $17,180,656$ & 14,759,260 & $34,057,550$ \\
\hline $\begin{array}{c}\text { Genomic position } \\
\text { (GRCh38/hg38) }\end{array}$ & Chr8:126,397,316-143,577,971 & Chr18:14,316-14,773,575 & Chrx:106,283,188-140,340,737 \\
\hline Clinical findings & $\begin{array}{c}\text { ID; microcephaly; seizures; } \\
\text { speech delay; global } \\
\text { developmental delay }\end{array}$ & $\begin{array}{c}\text { ID; speech delay; anxiety; } \\
\text { learning difficulty; } \\
\text { psychomotor agitation }\end{array}$ & $\begin{array}{c}\text { ID; NPMDD; short stature; } \\
\text { clinodactyly; } \\
\text { blepharophimosis }\end{array}$ \\
\hline
\end{tabular}

ID: Intellectual disability; NPMDD: neuropsychomotor development delay. ${ }^{*}$ age in years at the time of the CMA investigation.

a

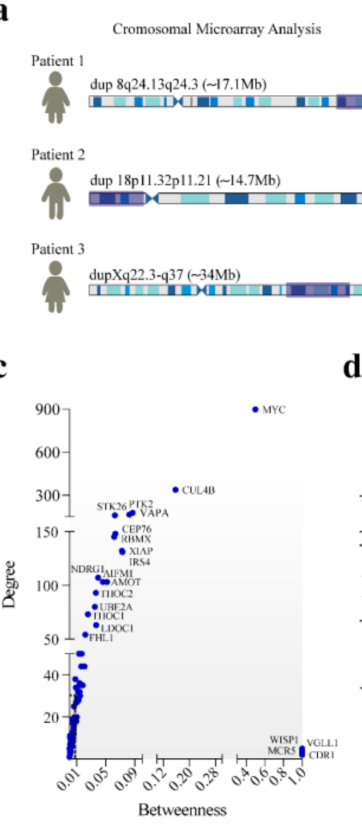

b

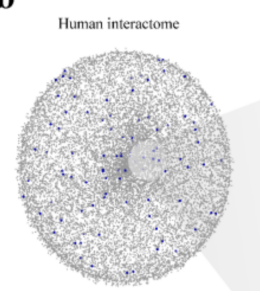

d

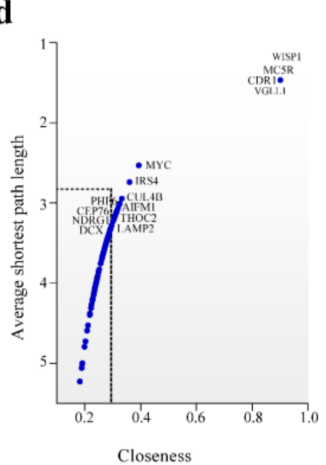

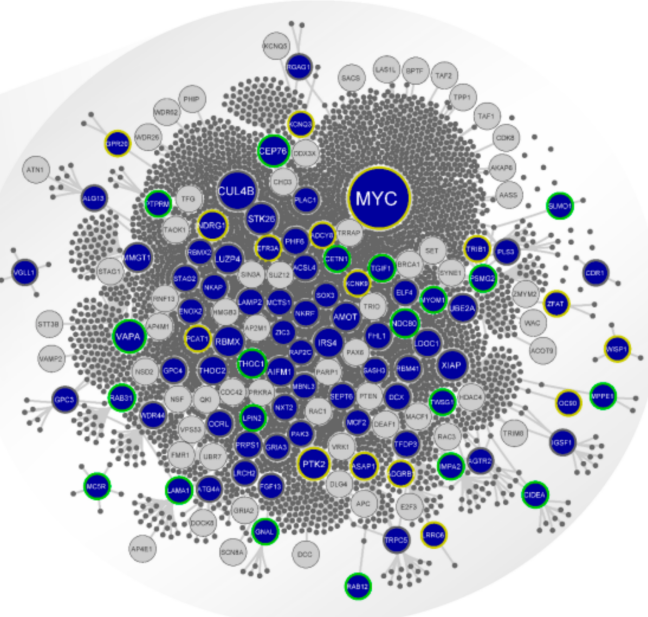

Figure 1. Cytogenetic to the interactome. (a) left: duplicated regions mapped by CMA in the patients; right: curated human interactome composed of 13,460 proteins and 141,296 interactions. In the network, proteins are nodes connected by interactions. (b) expanded duplication syndromes interactome (eDSi) with 3016 proteins and 4330 interactions. Blue nodes are protein-coding genes from duplicate regions; grey nodes are ID-genes. Node border colors represent the origin of duplication: dup 8q24.13q24.3 in yellow; dup 18p11.32p11.21 in green; dupXq22.3-q27 in grey. Node size is related to the number of connections (degree). (c) Topological parameters with degree and betweenness distribution and values of (d) average shortest path length and closeness for duplicated protein-coding genes in eDSi. Dashed lines in black indicate the average of these parameters for human interactome.

The average centrality measures in the human interactome were: degree (31.85), betweenness (0.00013), closeness (0.3249), and shortest path length (3.119). Degree centrality defines the number of connections of a specific node in the network, and in the biological context, nodes with a degree value $>100$ links (hubs) may have multiple functions in cellular networks [36]. Betweenness corresponds to the number of nonredundant shortest paths that pass through a node of interest and may indicate the potential of a protein to create a bridge for communication between distant nodes $[37,38]$. The average shortest path length involves the summa of all shortest paths between nodes couples, divided by all pairs of nodes in the network, and the closeness indicates how close a node is to all other nodes in the network $[39,40]$. 
Many DSi-proteins showed higher values of centrality, compared to the mean of the human interactome, indicating topological relevance to specific DSi-proteins (Figure 1c). In this sense, $14 \%$ of DSi-proteins were considered hubs, including MYC, a transcription factor, and CUL4B, a central component of the ubiquitin-protein ligase complex, both acting in several biological processes. Moreover, other hubs, such as RBMX, PTK2, AIFM1, VAPA, and XIAP, are associated with ID [41-45].

Eighty percent of the DSi-proteins reached a betweenness centrality value higher than the average of the human interactome (Figure 1c). VGLL1 (coactivator for the mammalian TEFs), CDR1 (neuronal signal transduction protein), MC5R (melanocortin receptor coupled to the transmembrane G protein), and WISP1 (a member of the WNT1 inducible signaling pathway) showed high betweenness values. All of these proteins have significant roles in signal transduction or coactivation of transcription factors [46-49]. Furthermore, CDR1 is a putative neuronal protein identified in individuals with cerebellar degeneration [50].

Besides degree and betweenness, shortest path length and closeness were calculated. VGLL1, CDR1, WISP1, and MC5R also emerged in the network with high closeness and lower shortest path length values (Figure 1c). From a biological perspective, these nodes can have a major impact on proteins that are close to the node or serve as the shortest path among distant proteins in the network. About $22 \%$ of the proteins were identified with values of closeness and shortest path length above the average of the interactome. The main results of the topological characteristics of other DSi-proteins can be seen in Figure 1c,d.

\subsection{Biological Processes Associated with Rare Duplications}

We carried out enrichment analysis of the DSi-proteins to identify biological processes with a possible role in ID. Six clusters were detected grouping the main bioprocesses (Figure 2). Cluster 1 identified only proteins from dup18p11.32p11.21 with enriched bioprocesses related to chromosome segregation. DSi-proteins from 8q24.13q24.3, 18p11.32p11.21, and Xq22.3q27.2 were found in clusters 2 and 6, associated with telomere maintenance, DNA repair, epithelium developmental, and ion transport. Cell morphogenesis in clusters 3 and 4 was associated with proteins from duplicated regions on chromosomes 8,18 , and $\mathrm{X}$. Cluster 5 is the only one to encompass proteins from the three duplicated regions, with enrichment for microtubule cytoskeleton organization, negative regulation of cell cycle, and neurogenesis. Cell pathways involving the ID pathophysiology can encompass changes in the cytoskeleton dynamics, neurogenesis, and morphology during synaptic plasticity or neuronal development $[11,51]$.

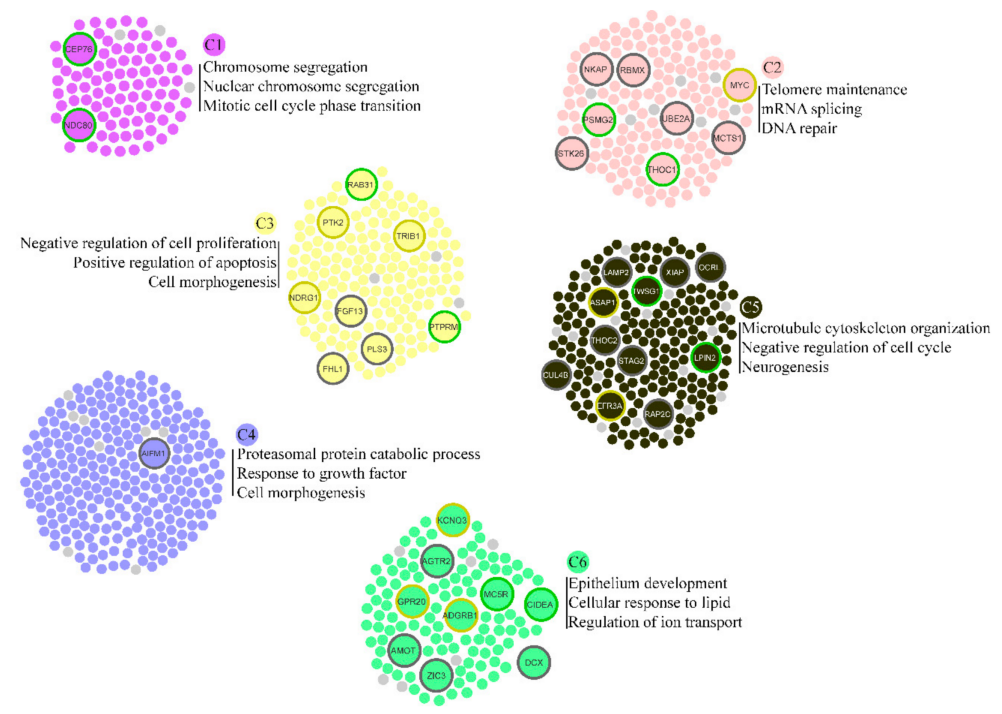

Figure 2. Functional cluster detection in eDSi. Node border colors represent the origin of duplication: dup 8q24.13q24.3 in yellow; dup 18p11.32p11.21 in green; dupXq22.3-q27 in grey. Small nodes in light grey represent ID-genes. 
In addition, plasma membrane-bounded cell projection was enriched in the three duplicated regions. This process involves the formation of a prolongation bounded by the plasma membrane, such as an axon. Projection defects were reported in an ID mouse model [52]. Moreover, neuronal development and nuclear chromosome segregation were identified in functional enrichment analysis of ID-genes and DSi-genes from dupXq22.3q27.2 and dup18p11.32p11.21. The complete results are provided in Supplementary Table S3.

\subsection{DSi-Genes Are Widely Expressed in the CNS}

ID is caused by perturbations in the significant biological functions that impact cellular networks present in different regions of the CNS. We identified the influence of each of the 44 prioritized genes (Supplementary Table S5) in different tissues and found that these genes are mainly expressed in the CNS when compared with other tissues in humans (Figure 3) $[14,16,53]$.

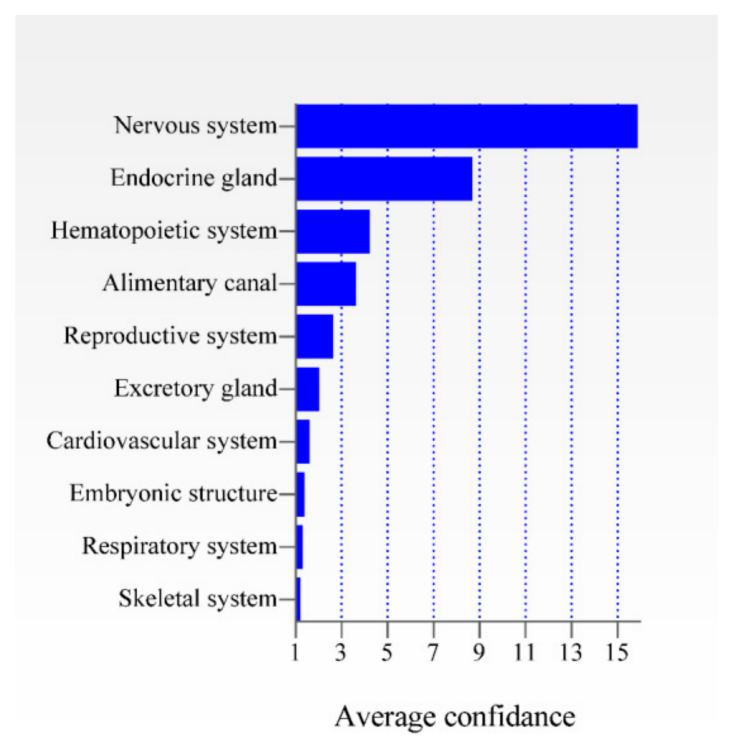

Figure 3. Expression of the 44 prioritized genes in ten different tissues. The average confidence value is shown for each tissue.

Therefore, we extracted expression data from multiple CNS regions to better understand the influence of each gene on this tissue (Figure 4). Many genes located at Xq22.3q27.2 are widely expressed in the CNS and were previously associated with syndromic/nonsyndromic X-linked ID, such as ALG13, PAK3, THOC2, GRIA3, STAG2, OCRL1, AIFM1, PHF6, RMBX, SOX3, LAMP2, CUL4B, and UBE2A [54,55]. Moreover, patients with duplicated regions that encompass the X-linked genes SOX3, STAG2, AIFM1, GRIA3, PAK3, and OCRL exhibit ID [22-26,56-58]. Moreover, six genes from the duplicated region 18p11.32p11.21 are highly expressed in several regions of the CNS, from which three of them (LAMA1, MYOM1, and TGIF1) were duplicated in individuals with ID [18-20]. Furthermore, patients with duplication of 8q24.13q24.3 region involving the KCNQ3, PTK2, ASAP1, and NDRG1 genes, which are widely expressed in CNS, presented ID $[14,16,53]$.

3.5. Candidate Proteins from Different Chromosome Rearrangements Interact with Each Other in the CNS Network

To analyze the relevance of candidate proteins according to tissue specificity, we constructed a network with interactions from the CNS, in an attempt to identify clues about the likely contribution of each protein in the development of ID. The CNS network includes 32 nodes connected by 210 interactions, from which 18 are DSi proteins (Figure 5a). The most connected proteins are PTK2 (19), STAG2 (16), and TGIF1 (16). Interestingly, ID-genes WAC, QKI, and PPP1R12A emerge as interacting factors on the network by automatic addition of the database. It is worth mentioning that many links in the tissue-specific network result 
from gene co-expression studies in the context of neurological conditions, such as recessive X-linked dystonia-parkinsonism, Rett syndrome, and Huntington's disease.

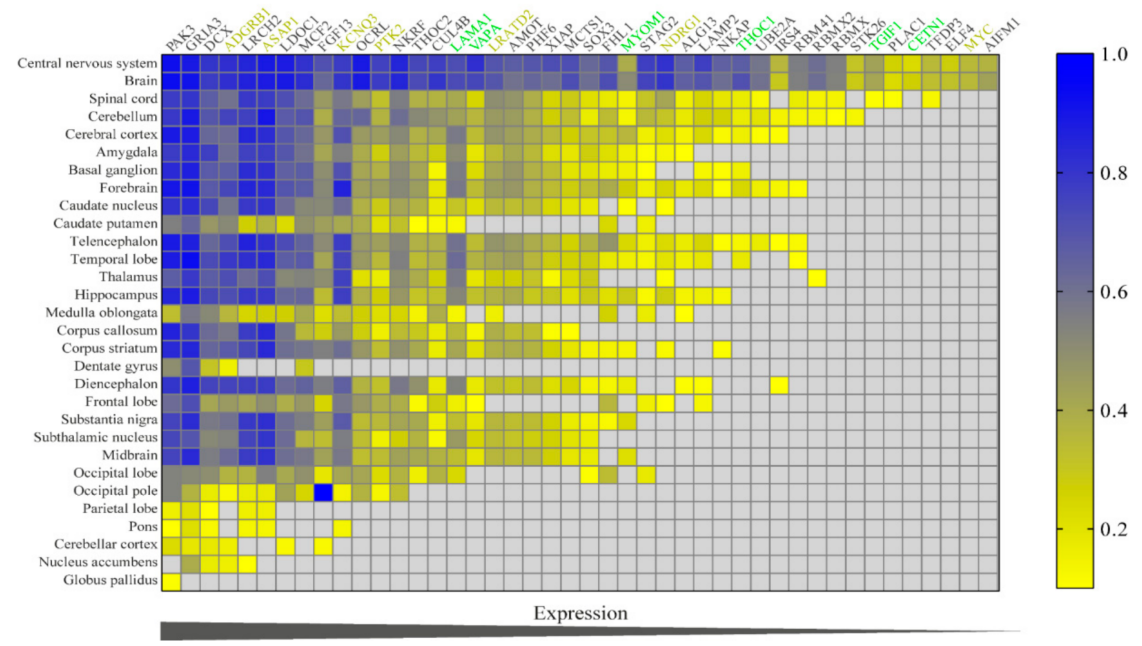

Figure 4. Heat map of expression of the 44 prioritized genes in CNS. Confidence value is calculated between $0-1$.

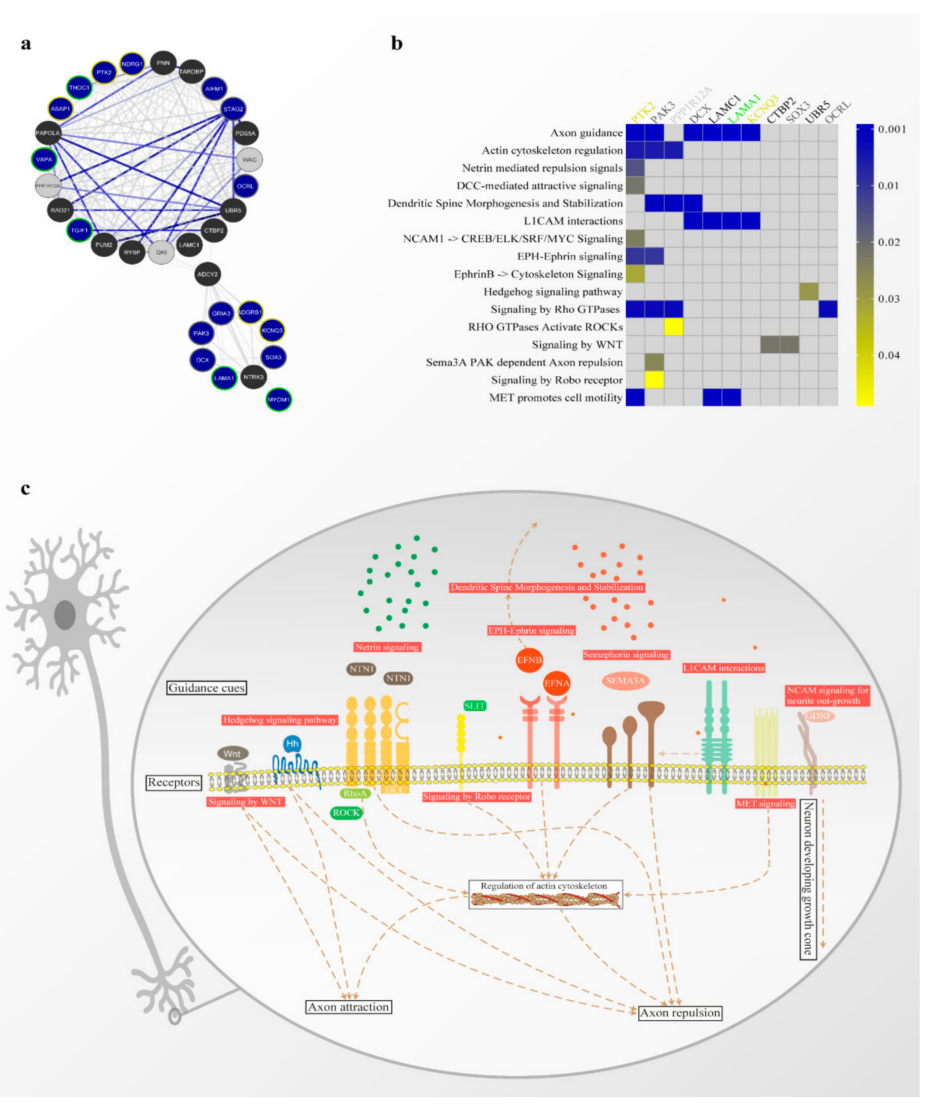

Figure 5. Tissue-specific gene network analysis. (a) functional network from CNS. Blue nodes are protein-coding genes from duplicate regions; grey nodes are ID-genes; black nodes were added by the database. Node border colors represent the origin of duplication: dup 8q24.13q24.3 in yellow; dup 18p11.32p11.21 in green; dupXq22.3-q27 in grey. Score values are shown proportionally by the thickness and intensity color of the edges. (b) heat map of genes from tissue-specific gene network with the most significant biological processes. (c) Scheme depicting the main pathways and molecules involved in axon guidance. 
The functional enrichment analysis identified several pathways associated with axon guidance (Figure 5b). The genes directly involved with this biological process include PTK2 and KCNK3 (dup 8q24.13q24.3), LAMA1 (dup 18p11.32p11.21), and PAK3, DCX, SOX3, and OCRL (dupXq22.3-q27). As mentioned above, all these genes have already been identified in duplicated regions in individuals with ID. Moreover, LAMA1 was also present in our IDlist which used the candidate genes prioritization. Pathways related to functions necessary to axon guidance that encompasses these genes, include actin cytoskeleton regulation $(p=0.0060)$, L1CAM interactions $(p<0.0001)$, EPH-ephrin signaling $(p=0.0107)$, signaling by Rho GTPases $(p=0.0029)$ and MET cell motility promotion $(p=0.0003)$. However, other fundamental pathways in the axon guidance context can be seen in Figure $5 \mathrm{~b}$. The PPP1R12A gene, added to the database, is the only one not belonging to the duplicated region that appears in the ID-genes list and is involved in axon guidance.

Taken together, these results indicate that genes from different duplicated regions may be related to each other and other genes previously associated with ID localized in cellular networks in the nervous tissue and involved in neurodevelopment processes (Figure 5c).

\subsection{Candidate Genes Are Associated with the ID}

Similar pathways are disrupted in ID and in other neurological diseases due to the functional relationships of genes located in the same module in the human interactome. Therefore, to identify DSi-genes implicated in other neurological diseases, and help to confirm our results, we generated a gene-disease association network (Figure 6).

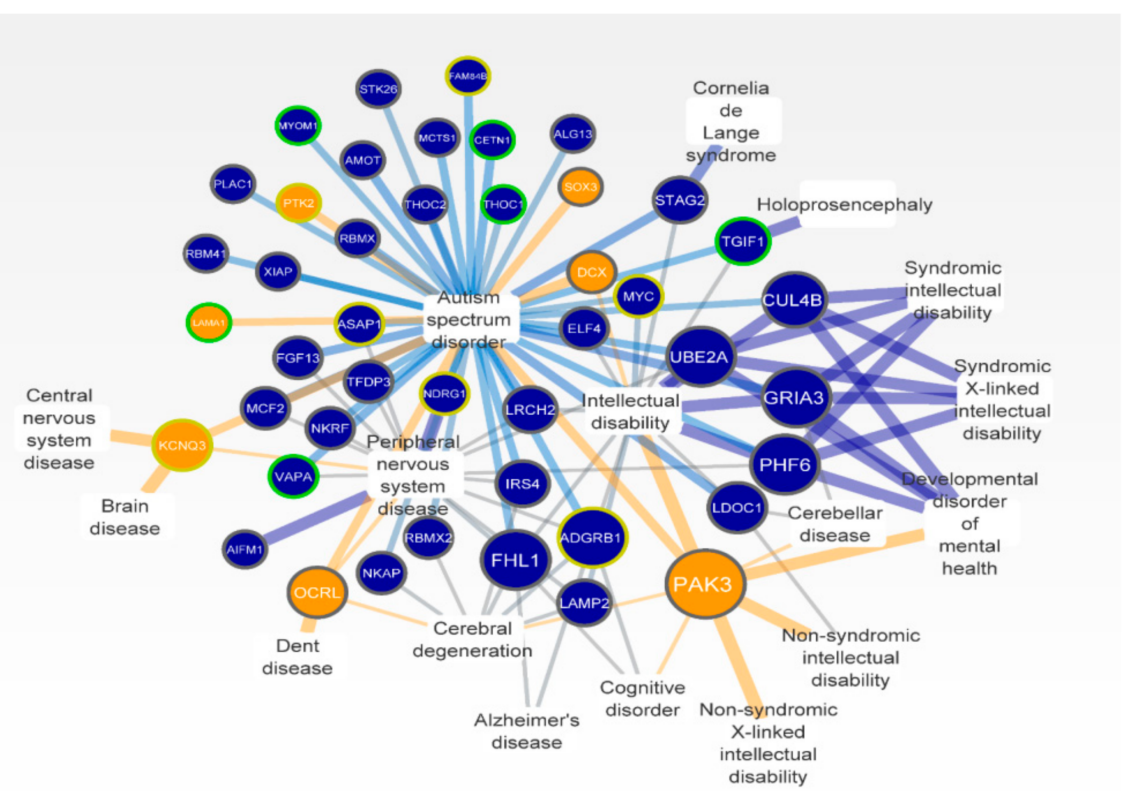

Figure 6. Gene-disease associations network. Duplicated genes (circular nodes) and disease of CNS (rectangular nodes). The size of the circle nodes corresponds to the number of diseases associated. Blue nodes are protein-coding genes from duplicate regions; orange nodes are candidate genes. Node border colors represent the origin of duplication: dup 8q24.13q24.3 in yellow; dup 18p11.32p11.21 in green; dupXq22.3-q27 in grey. Scores values are shown proportionally by the thickness and intensity color of the edges. Orange edges show interactions of candidate genes.

The most common diseases or phenotypes found on the network were autism spectrum disorder, peripheral CNS disease, and ID with 43, 17, and 15 associated genes, respectively. Maximum scores between disease and genes were seen in brain disease, holoprosencephaly, syndromic/non-syndromic ID, and syndromic/non-syndromic X-linked ID. The genes with the highest number of connections with other diseases were PAK3, GRIA3, and ADGRB1 associated with eight, six, and six neurological diseases, respectively. As expected, these genes were the most expressed in the CNS tissue (Figure 3). Previous 
data support the known relationships of many genes on the network with neurological diseases, especially located in Xq22.3-q27.2 [55]. Moreover, the candidate genes PAK3, OCRL, DCX, PTK2, KCNQ3, SOX3, and LAMA1 were associated with autism, brain disease, Dent disease, and other conditions that present ID as a hallmark, corroborating our findings (Figure 6).

\section{Discussion}

Genomic disorders caused by duplications of chromosome segments confer potential risk of global developmental delay and ID, impacting the IQ, and educational achievement of individuals [59-61]. The imbalance in gene dosage caused by chromosomal duplications can destabilize several genes by spreading through interactions in cellular subnetworks during neurodevelopment. Moreover, the chromosome rearrangements identified in our patients are rare, with few cases reported so far. These duplicated regions have been reported as pathogenic and ID is a recurrent clinical finding in the affected individuals $[16,21,26]$. Therefore, we used network analysis in an attempt to identify the potential sharing of biological processes and genes responsible for the pathophysiology of ID in rare duplications. We found seven candidate genes: PTK2 and KCNK3 (dup 8q24.13q24.3), LAMA1 (dup 18p11.32p11.21), and $P A K 3, D C X, S O X 3$, and OCRL from dupXq22.3q27, all duplicated in individuals with ID $[15,16,19,23,25,55-57,61]$. Furthermore, all candidate genes identified have been reported in duplicated regions of several ID patients in the web-based database-DECIPHER.

PTK2, protein tyrosine kinase 2, emerged with high degree and betweenness values (hub-bottleneck) through topological analysis in the eDSi (Figure 1c). This result correctly reflects the many biological functions performed by PTK2 that involve the regulation of migration, adhesion, protrusion, and proliferation of the cell. Besides that, PTK2 promotes axon growth and guidance and synapse formation during CNS development [62-65]. Therefore, changes in PTK2 expression can impair brain development and lead to mental conditions [66]. Our topological analysis supports the identification of candidate disease genes that tend to be more central to the network, and not in peripheral regions as we expected $[67,68]$. Moreover, we identified many proteins from duplicated regions with high betweenness values considered bottlenecks, essential nodes in the information flow between distant proteins in cellular networks [38], indicating a potential impact in pathophysiology, when dysregulated.

We identified significant expression of duplicated genes in the CNS conversely to other tissues (Figure 3). Moreover, candidate genes present remarkable expression in regions of CNS associated with ID (Figure 4), such as the cortical region and the cerebellum [10]. Candidate genes from different chromosomes interact with each other in the tissue-specific network, demonstrating functional relationships among these genes in the CNS. For instance, PTK2 (chr:8) interacts directly with OCRL (inositol polyphosphate-5-phosphatase-chr:X), DCX (doublecortin—chr:X) with LAMA1 (laminin subunit $\alpha 1-$ chr:18), or yet, KCNQ3 (potassium voltage-gated channel subfamily $\mathrm{Q}$ member 3-chr:8) and LAMA1 are connected to each other by the neurotrophic tyrosine receptor kinase (NTRK3) (Figure 5a). Furthermore, OCRL and PTK2 interacts directly with $W A C, Q K I$, and $P P P 1 R 12 A$, genes previously associated with ID [69-72]. In the case of PPP1R12A, its loss-of-function causes holoprosencephaly and ID in individuals with stop gain variants and deletions/duplications, resulting in a frameshift effect [72]. PPP1R12A protein is present in pathways, such as RHO actin cytoskeleton regulation, ROCKs activation by GTPases, dendritic spine morphogenesis, and stabilization, all bioprocesses directly or indirectly involved with axon guidance mechanisms.

Axon guidance was the most enriched term in the tissue-specific network, besides the identification of various signaling pathways directly or indirectly involved in this biological process (Figure $5 b$ ). The axon guidance process plays an essential function in neuronal wiring in the developing spinal cord, where it is responsible for extending axons and reaching their targets to form synaptic junctions. These mechanisms allow the connection between the central and peripheral nervous system during neurodevelopment, through extracellular and transmembrane molecules and their cell surface receptors [73-75]. The main axon guidance 
pathways and mechanisms involving our candidate genes were schematized in Figure 5c. The disruption or disintegration of neural circuit formation during CNS development affects cognitive function and can result in mental conditions such as ID [76-78]. The current model of the axon orientation mechanism reveals that the expression of guidance receptors occurs in the growth cone to indicate their targets and allow migration by controlling attractive and repulsive forces containing many guidance molecules present in their environment [75,77]. Therefore, the model of neural circuit formation supports the idea that changes in gene dosage caused by chromosomal duplications may impair the balance of this mechanism during the CNS development [79], where the gain or loss-of-function can impair the tight regulation of gene sets and cause disturbances in neighbor proteins in networks. However, expression data from patients with these chromosomal duplications should be used to confirm this model.

We observed interactions in the gene-disease association network between neurological conditions with ID and DSi-genes of three different chromosomes (Figure 6). These data suggest that duplicated regions could generate perturbations and propagate through modules in the interactome associated with many diseases linked to the CNS. For instance, the partial duplication of the gene that encodes the neuronal development transcription factor SOX3 can cause impairment in pituitary development and cognitive functions [80]. PAK3 is expressed in the brain, playing a role in the control of cytoskeleton regulation, cell migration, axonal guidance, and synaptic plasticity, while its deregulation causes neurological abnormalities, such as ID [81,82]. PAK3 pathogenic variants in affected males were associated with spatial cognitive abilities, defects in attention, and speech difficulties $[83,84]$, and a hemizygous missense variant in this gene was found in two male siblings with ID [85]. $O C R L$ regulates the traffic in the endosomal machinery and its depletion affects the recycling of various classes of receptors [86]. Dent disease patients with pathogenic variants in the OCRL can present mental impairment $[87,88]$. Already, $D C X$ plays a crucial role in the CNS, enhancing the axonal outgrowth in postnatal cortical neurons [89]. Variants in DCX result in X-linked lissencephaly in males, and its overexpression leads to destabilization of microtubules and inhibition of neurite outgrowth [90]. Beyond the PTK2 gene (a duplicated region on chromosome 8), KCNQ3 encodes a protein with functions in the regulation of neuronal excitability and plasticity $[91,92]$. Pathogenic variants in this gene were identified in patients with early-onset epilepsy and neurocognitive deficits [93]. Moreover, a gain of function variants in KCNQ3 causes neurodevelopmental delay and autistic features [94]. Lastly, LAMA1 (duplicated region on chromosome 18), laminin involved in cell adhesion and axon outgrowth during embryonic development is associated with cerebellar dysplasia and ID in individuals with homozygous variants [95-98].

The phenotype in these conditions is not only the result of deficient protein, but also perturbations that spread in the cellular networks. Therefore, the network-based analysis, regardless of the origin of the pathogenesis of chromosomal duplications (epigenetic alteration, gain of function, effect of position, change of transcription factor sites, or deregulation of miRNAs), can help to predict the consequence of these mechanisms by analyzing functional protein relationships and their interactions in a network $[99,100]$.

\section{Conclusions}

We found functional relationships among genes from three different duplicated chromosomal regions, reflecting interactions of protein-coding genes and their involvement in common cellular subnetworks. Furthermore, the sharing of common significant biological processes associated with ID has been demonstrated between proteins from the different chromosomal regions. According to our results, we indicate potential molecules and signaling pathways responsible for neuronal wiring that can be deregulated during neurodevelopment and cause ID. Further analysis of gene expression would be necessary to generate experimental data for these conditions in order to show more evidence regarding the association between gene expression and ID. 
Supplementary Materials: The following are available online at https:/ / www.mdpi.com/article/ 10.3390/genes12050632/s1. Supplementary S1: Chromosomal Microarray Analysis ratio profiles of the dup 8q24.13q24.3; dup 18p11.32p11.21 and dupXq22.3-q27. Table S1. List of proteins present in the human interactome from duplicated regions. Table S2. The compiled human interactomeHIPPIE V 2.2. Score $>0.4$. Table S3. Functional module detection-GO version. Table S4. Curated gene-disease associations. Table S5. List of proteins from expand node selection using network propagation algorithms.

Author Contributions: Conceptualization: T.C. and M.R.; methodology: T.C.; software: T.C.; formal analysis: T.C.; investigation: T.C. and M.R.; writing-original draft preparation: all authors; writingreview \& editing: C.B.S.-R., M.M., A.S. and M.R.; visualization: T.C.; supervision: M.R.; funding acquisition: M.R. All authors have read and agreed to the published version of the manuscript.

Funding: T.C. and C.B.S.-R. are supported by Conselho Nacional de Desenvolvimento Científico e Tecnológico, Brazil (CNPq).

Institutional Review Board Statement: Not applicable.

Informed Consent Statement: Informed consent was obtained from all subjects involved in the study.

Conflicts of Interest: The authors declare no conflict of interest.

\section{References}

1. Carvalho, C.M.; Lupski, J.R. Mechanisms underlying structural variant formation in genomic disorders. Nat. Rev. Genet. 2016, 17, 224-238. [CrossRef] [PubMed]

2. Harel, T.; Lupski, J. Genomic disorders 20 years on-mechanisms for clinical manifestations. Clin. Genet. 2017, 93, 439-449. [CrossRef] [PubMed]

3. Cooper, G.M.; Coe, B.P.; Girirajan, S.; Rosenfeld, J.A.; Vu, T.H.; Baker, C.; A Williams, C.; Stalker, H.J.; Hamid, R.; Hannig, V.; et al. A copy number variation morbidity map of developmental delay. Nat. Genet. 2011, 43, 838-846. [CrossRef] [PubMed]

4. Vissers, L.E.L.M.; Gilissen, C.; Veltman, J.A. Genetic studies in intellectual disability and related disorders. Nat. Rev. Genet. 2016, 17, 9-18. [CrossRef]

5. Papp, B.; Pál, C.; Hurst, L.D. Dosage sensitivity and the evolution of gene families in yeast. Nature 2003, 424, 194-197. [CrossRef]

6. Cabrejo, L.; Guyant-Maréchal, L.; Laquerrière, A.; Vercelletto, M.; De La Fournière, F.; Thomas-Antérion, C.; Verny, C.; Letournel, F.; Pasquier, F.; Vital, A.; et al. Phenotype associated with APP duplication in five families. Brain 2006, 129, 2966-2976. [CrossRef]

7. Maulik, P.K.; Mascarenhas, M.N.; Mathers, C.D.; Dua, T.; Saxena, S. Prevalence of intellectual disability: A meta-analysis of population-based studies. Res. Dev. Disabil. 2011, 32, 419-436. [CrossRef]

8. Chiurazzi, P.; Pirozzi, F. Advances in Understanding-Genetic Basis of Intellectual Disability. F1000Research 2016, 5. [CrossRef]

9. Miller, D.T.; Adam, M.P.; Aradhya, S.; Biesecker, L.G.; Brothman, A.R.; Carter, N.P.; Church, D.M.; Crolla, J.A.; Eichler, E.E.; Epstein, C.J.; et al. Consensus Statement: Chromosomal Microarray Is a First-Tier Clinical Diagnostic Test for Individuals with Developmental Disabilities or Congenital Anomalies. Am. J. Hum. Genet. 2010, 86, 749-764. [CrossRef]

10. Verma, V.; Paul, A.; Vishwanath, A.A.; Vaidya, B.; Clement, J.P. Understanding intellectual disability and autism spectrum disorders from common mouse models: Synapses to behaviour. Open Biol. 2019, 9, 180265. [CrossRef]

11. Van Bokhoven, H. Genetic and Epigenetic Networks in Intellectual Disabilities. Annu. Rev. Genet. 2011, 45, 81-104. [CrossRef]

12. Menche, J.; Sharma, A.; Kitsak, M.; Ghiassian, S.D.; Vidal, M.; Loscalzo, J.; Barabási, A.-L. Uncovering disease-disease relationships through the incomplete interactome. Science 2015, 347, 1257601. [CrossRef]

13. Bonaglia, M.C.; Giorda, R.; Tenconi, R.; Pessina, M.; Pramparo, T.; Borgatti, R.; Zuffardi, O. A 2.3 Mb duplication of chromosome 8q24.3 associated with severe mental retardation and epilepsy detected by standard karyotype. Eur. J. Hum. Genet. 2005, 13, 586-591. [CrossRef]

14. Concolino, D.; Iembo, M.A.; Moricca, M.T.; Rapsomaniki, M.; Marotta, R.; Galesi, O.; Fichera, M.; Romano, C.; Strisciuglio, P. A de Novo 8q22.2-24.3 Duplication in a Patient with Mild Phenotype. Eur. J. Med. Genet. 2012, 55, 67-70. [CrossRef]

15. Wheeler, P.G. 8q23-Q24 Duplication-Further Delineation of a Rare Chromosomal Abnormality. Am. J. Med. Genet. Part A 2010, 152, 459-463. [CrossRef]

16. Rezek, R.F.; Rodrigues Abbas, A.A.; Forte Mazzeu, J.; Duarte Miranda, S.M.; Velloso-Rodrigues, C. A Rare Interstitial Duplication of 8q22.1-8q24.3 Associated with Syndromic Bilateral Cleft Lip/Palate. Case Rep. Dent. 2014, 2014, 1-4. [CrossRef]

17. Orendi, K.; Uhrig, S.; Mach, M.; Tschepper, P.; Speicher, M.R. Complete and Pure Trisomy 18p Due to a Complex Chromosomal Rearrangement in a Male Adult with Mild Intellectual Disability. Am. J. Med. Genet. Part A 2013, 161, 1806-1812. [CrossRef]

18. Balasubramanian, M.; Sithambaram, S.; Smith, K. Inherited Duplication of the Short Arm of Chromosome 18p11.32-P11.31 Associated with Developmental Delay/Intellectual Disability. Clin. Dysmorphol. 2016, 25, 19-22. [CrossRef]

19. Giordano, M.; Muratore, V.; Babu, D.; Meazza, C.; Bozzola, M. A 18p11.23-P11.31 Microduplication in a Boy with Psychomotor Delay, Cerebellar Vermis Hypoplasia, Chorioretinal Coloboma, Deafness and GH Deficiency. Mol. Cytogenet. 2016, 9, 10-15. [CrossRef] 
20. Kashevarova, A.A.; Nazarenko, L.P.; Skryabin, N.A.; Nikitina, T.V.; Vasilyev, S.A.; Tolmacheva, E.N.; Lopatkina, M.E.; Salyukova, O.A.; Chechetkina, N.N.; Vorotelyak, E.A.; et al. A Mosaic Intragenic Microduplication of LAMA1 and a Constitutional 18p11.32 Microduplication in a Patient with Keratosis Pilaris and Intellectual Disability. Am. J. Med. Genet. Part A 2018, 176, 2395-2403. [CrossRef]

21. Wang, R.; Zhang, H.; Li, L.; Yue, F.; Jiang, Y.; Li, S.; Liu, R. Prenatal Detection of Interstitial 18p11.31-P11.22 Microduplications: Phenotypic Diversity and Literature Review. Prenat. Diagn. 2019, 39, 1120-1126. [CrossRef] [PubMed]

22. Philippe, A.; Malan, V.; Jacquemont, M.L.; Boddaert, N.; Bonnefont, J.P.; Odent, S.; Munnich, A.; Colleaux, L.; Cormier-Daire, V. Xq25 Duplications Encompassing GRIA3 and STAG2 Genes in Two Families Convey Recognizable X-Linked Intellectual Disability with Distinctive Facial Appearance. Am. J. Med. Genet. Part A 2013, 161, 1370-1375. [CrossRef] [PubMed]

23. Møller, R.S.; Jensen, L.R.; Maas, S.M.; Filmus, J.; Capurro, M.; Hansen, C.; Marcelis, C.L.M.; Ravn, K.; Andrieux, J.; Mathieu, M.; et al . X-Linked Congenital Ptosis and Associated Intellectual Disability, Short Stature, Microcephaly, Cleft Palate, Digital and Genital Abnormalities Define Novel Xq25q26 Duplication Syndrome. Hum. Genet. 2014, 133, 625-638. [CrossRef]

24. Kumar, R.; Corbett, M.A.; Van Bon, B.W.M.; Gardner, A.; A.Woenig, J.; Jolly, L.A.; Douglas, E.; Friend, K.; Tan, C.; Van Esch, H.; et al. Increased STAG2 Dosage Defines a Novel Cohesinopathy with Intellectual Disability and Behavioral Problems. Hum. Mol. Genet. 2015, 24, 7171-7181. [CrossRef] [PubMed]

25. Leroy, C.; Jacquemont, M.L.; Doray, B.; Lamblin, D.; Cormier-Daire, V.; Philippe, A.; Nusbaum, S.; Patrat, C.; Steffann, J.; Colleaux, L.; et al. Xq25 Duplication: The Crucial Role of the STAG2 Gene in This Novel Human Cohesinopathy. Clin. Genet. 2016, 89, 68-73. [CrossRef] [PubMed]

26. Li, L.; Fu, F.; Li, R.; Xiao, W.; Yu, Q.; Wang, D.; Jing, X.; Zhang, Y.; Yang, X.; Pan, M.; et al. Genetic Tests Aid in Counseling of Fetuses with Cerebellar Vermis Defects. Prenat. Diagn. 2020, 40, 1228-1238. [CrossRef] [PubMed]

27. Alanis-Lobato, G.; Andrade-Navarro, M.A.; Schaefer, M.H. HIPPIE v2.0: Enhancing Meaningfulness and Reliability of ProteinProtein Interaction Networks. Nucleic Acids Res. 2017, 45, D408-D414. [CrossRef] [PubMed]

28. Shannon, P.; Markiel, A.; Ozier, O.; Baliga, N.S.; Wang, J.T.; Ramage, D.; Amin, N.; Schwikowski, B.; Ideker, T. Cytoscape: A Software Environment for Integrated Models of Biomolecular Interaction Networks. Genome Res. 2003, 2498-2504. [CrossRef]

29. Ju, W.; Greene, C.S.; Eichinger, F.; Nair, V.; Hodgin, J.B.; Bitzer, M.; Lee, Y.S.; Zhu, Q.; Kehata, M.; Li, M.; et al. Defining Cell-Type Specificity at the Transcriptional Level in Human Disease. Genome Res. 2013, 23, 1862-1873. [CrossRef]

30. Greene, C.S.; Krishnan, A.; Wong, A.K.; Ricciotti, E.; Zelaya, R.A.; Himmelstein, D.S.; Zhang, R.; Hartmann, B.M.; Zaslavsky, E.; Sealfon, S.C.; et al. Understanding Multicellular Function and Disease with Human Tissue-Specific Networks. Nat. Genet. 2015, 47, 569-576. [CrossRef]

31. Krishnan, A.; Zhang, R.; Yao, V.; Theesfeld, C.L.; Wong, A.K.; Tadych, A.; Volfovsky, N.; Packer, A.; Lash, A.; Troyanskaya, O.G. Genome-Wide Prediction and Functional Characterization of the Genetic Basis of Autism Spectrum Disorder. Nat. Neurosci. 2016, 19, 1454-1462. [CrossRef]

32. Kuleshov, M.V.; Jones, M.R.; Rouillard, A.D.; Fernandez, N.F.; Duan, Q.; Wang, Z.; Koplev, S.; Jenkins, S.L.; Jagodnik, K.M.; Lachmann, A.; et al. Enrichr: A Comprehensive Gene Set Enrichment Analysis Web Server 2016 Update. Nucleic Acids Res. 2016, 44, W90-W97. [CrossRef]

33. Piñero, J.; Ramírez-Anguita, J.M.; Saüch-Pitarch, J.; Ronzano, F.; Centeno, E.; Sanz, F.; Furlong, L.I. The DisGeNET Knowledge Platform for Disease Genomics: 2019 Update. Nucleic Acids Res. 2020, 48, D845-D855. [CrossRef]

34. Carlin, D.E.; Demchak, B.; Pratt, D.; Sage, E.; Ideker, T. Network Propagation in the Cytoscape Cyberinfrastructure. PLoS Comput. Biol. 2017, 13, e1005598. [CrossRef]

35. Piñero, J.; Bravo, Á.; Queralt-Rosinach, N.; Gutiérrez-Sacristán, A.; Deu-Pons, J.; Centeno, E.; García-García, J.; Sanz, F.; Furlong, L.I. DisGeNET: A Comprehensive Platform Integrating Information on Human Disease-Associated Genes and Variants. Nucleic Acids Res. 2017, 45, D833-D839. [CrossRef]

36. Loscalzo, J.; Barabási, A.L.; Silverman, E.K. Network Medicine: Complex Systems in Human Disease and Therapeutics; Havard University Press: London, UK, 2017.

37. Girvan, M.; Newman, M.E.J. Community Structure in Social and Biological Networks. Proc. Natl. Acad. Sci. USA 2002, 99, 7821-7826. [CrossRef]

38. Yu, H.; Kim, P.M.; Sprecher, E.; Trifonov, V.; Gerstein, M. The Importance of Bottlenecks in Protein Networks: Correlation with Gene Essentiality and Expression Dynamics. PLoS Comput. Biol. 2007, 3, e59. [CrossRef]

39. Freeman, L.C. Centrality in Social Networks. Soc. Netw. 1979, 1, 215-239. [CrossRef]

40. Newman, M.E.J. Scientific Collaboration Networks. II. Shortest Paths, Weighted Networks, and Centrality. Phys. Rev. E Stat. Phys. Plasmas Fluids Relat. Interdiscip. Top. 2001, 64, 7. [CrossRef]

41. Zou, Y.; Liu, Q.; Chen, B.; Zhang, X.; Guo, C.; Zhou, H.; Li, J.; Gao, G.; Guo, Y.; Yan, C.; et al. Mutation in CUL4B, Which Encodes a Member of Cullin-RING Ubiquitin Ligase Complex, Causes X-Linked Mental Retardation. Am. J. Hum. Genet. 2007, 80, 561-566. [CrossRef]

42. Di Gregorio, E.; Bianchi, F.T.; Schiavi, A.; Alessandra, M.A.; Rolando, M.; Verdun, L.; Grosso, E.; Calcia, A.; Lacerenza, D.; Zuffardi, O.; et al. A de novo X;8 translocation creates a PTK2-THOC2 gene fusion with THOC2 expression knockdown in a patient with psychomotor retardation and congenital cerebellar hypoplasia. J. Med. Genet. 2014, 50, 543-551. [CrossRef] [PubMed] 
43. Shashi, V.; Xie, P.; Schoch, K.; Goldstein, D.B.; Howard, T.D.; Berry, M.N.; Schwartz, C.E.; Cronin, K.; Sliwa, S.; Allen, A.; et al. The RBMX Gene as a Candidate for the Shashi X-Linked Intellectual Disability Syndrome. Clin. Genet. 2015, 88, 386-390. [CrossRef] [PubMed]

44. Mierzewska, H.; Rydzanicz, M.; Biegański, T.; Kosinska, J.; Mierzewska-Schmidt, M.; Ługowska, A.; Pollak, A.; Stawiński, P.; Walczak, A.; Kędra, A.; et al. Spondyloepimetaphyseal Dysplasia with Neurodegeneration Associated with AIFM1 Mutation-A Novel Phenotype of the Mitochondrial Disease. Clin. Genet. 2017, 91, 30-37. [CrossRef] [PubMed]

45. Riazuddin, S.; Hussain, M.; Razzaq, A.; Iqbal, Z.; Shahzad, M.; Polla, D.L.; Song, Y.; Van Beusekom, E.; Khan, A.A.; Tomas-Roca, L.; et al. Exome Sequencing of Pakistani Consanguineous Families Identifies 30 Novel Candidate Genes for Recessive Intellectual Disability. Mol. Psychiatry 2017, 22, 1604-1614. [CrossRef]

46. Pennica, D.; Swanson, T.A.; Welsh, J.W.; Roy, M.A.; Lawrence, D.A.; Lee, J.; Brush, J.; Taneyhill, L.A.; Deuel, B.; Lew, M.; et al. WISP Genes Are Members of the Connective Tissue Growth Factor Family That Are Up-Regulated in Wnt-1-Transformed Cells and Aberrantly Expressed in Human Colon Tumors. Proc. Natl. Acad. Sci. USA 1998, 95, 14717-14722. [CrossRef]

47. Hatta, N.; Dixon, C.; Ray, A.J.; Phillips, S.R.; Cunliffe, W.J.; Dale, M.; Todd, C.; Meggit, S.; Birch-Machin, M.A.; Rees, J.L. Expression, Candidate Gene, and Population Studies of the Melanocortin 5 Receptor. J. Investig. Dermatol. 2001, 116, 564-570. [CrossRef]

48. Mahoney, W.M.; Hong, J.H.; Yaffe, M.B.; Farrance, I.K.G. The Transcriptional Co-Activator TAZ Interacts Differentially with Transcriptional Enhancer Factor-1 (TEF-1) Family Members. Biochem. J. 2005, 388, 217-225. [CrossRef]

49. Bosco, P.; Spada, R.; Caniglia, S.; Salluzzo, M.G.; Salemi, M. Cerebellar Degeneration-Related Autoantigen 1 (CDR1) Gene Expression in Alzheimer's Disease. Neurol. Sci. 2014, 35, 1613-1614. [CrossRef]

50. Dropchot, E.J.; Chen, Y.; Posnert, J.B.; Old, L.J. Cloning of a Brain Protein Identified by Autoantibodies from a Patient with Paraneoplastic Cerebellar Degeneration. Proc. Natl. Acad. Sci. USA 1987, 84, 4552-4556. [CrossRef]

51. Cappello, S. Small Rho-GTPases and Cortical Malformations: Fine-Tuning the Cytoskeleton Stability. Small GTPases 2013, 4, 51-56. [CrossRef]

52. Chen, L.; Liao, G.; Waclaw, R.R.; Burns, K.A.; Linquist, D.; Campbell, K.; Zheng, Y.; Kuan, C.Y. Rac1 Controls the Formation of Midline Commissures and the Competency of Tangential Migration in Ventral Telencephalic Neurons. J. Neurosci. 2007, 27, 3884-3893. [CrossRef]

53. Bruni, V.; Roppa, K.; Scionti, F.; Apa, R.; Sestito, S.; Di Martino, M.T.; Pensabene, L.; Concolino, D. A 46,XY Female with a 9p24.3p24.1 Deletion and a 8q24.11q24.3 Duplication: A Case Report and Review of the Literature. Cytogenet. Genome Res. 2019. [CrossRef]

54. Neri, G.; Schwartz, C.E.; Lubs, H.A.; Stevenson, R.E. X-Linked Intellectual Disability Update 2017. Am. J. Med. Genet. Part A 2018, 176, 1375-1388. [CrossRef]

55. Tejada, M.I.; Ibarluzea, N. Non-Syndromic X Linked Intellectual Disability: Current Knowledge in Light of the Recent Advances in Molecular and Functional Studies. Clin. Genet. 2020, 97, 677-687. [CrossRef]

56. Di Benedetto, D.; Musumeci, S.A.; Avola, E.; Alberti, A.; Buono, S.; Scuderi, C.; Grillo, L.; Galesi, O.; Spalletta, A.; Giudice, M.L.; et al. Definition of Minimal Duplicated Region Encompassing the XIAP and STAG2 Genes in the Xq25 Microduplication Syndrome. Am. J. Med. Genet. Part A 2014, 164, 1923-1930. [CrossRef]

57. Arya, V.B.; Chawla, G.; Nambisan, A.K.R.; Muhi-Iddin, N.; Vamvakiti, E.; Ajzensztejn, M.; Hulse, T.; Ferreira Pinto, C.; Lahiri, N.; Bint, S.; et al. Xq27.1 Duplication Encompassing SOX3: Variable Phenotype and Smallest Duplication Associated with Hypopituitarism to Date-A Large Case Series of Unrelated Patients and a Literature Review. Horm. Res. Paediatr. 2019. [CrossRef]

58. Jin, Z.; Yu, L.; Geng, J.; Wang, J.; Jin, X.; Huang, H. A Novel 47.2Mb Duplication on Chromosomal Bands Xq21.1-25 Associated with Mental Retardation. Gene 2015, 567, 98-102. [CrossRef]

59. Nishi, A.; Hiroi, N. Genetic Mechanisms Emerging from Mouse Models of CNV-Associated Neuropsychiatric Disorders; Elsevier Inc.: Amsterdam, The Netherlands, 2016; ISBN 9780128018774.

60. Bass, N.; Skuse, D. Genetic Testing in Children and Adolescents with Intellectual Disability. Curr. Opin. Psychiatry 2018, 31, 490-495. [CrossRef]

61. Huguet, G.; Schramm, C.; Douard, E.; Jiang, L.; Labbe, A.; Tihy, F.; Mathonnet, G.; Nizard, S.; Lemyre, E.; Mathieu, A.; et al. Measuring and Estimating the Effect Sizes of Copy Number Variants on General Intelligence in Community-Based Samples. JAMA Psychiatry 2018, 75, 447-457. [CrossRef]

62. Liu, G.; Beggs, H.; Jürgensen, C.; Park, H.T.; Tang, H.; Gorski, J.; Jones, K.R.; Reichardt, L.F.; Wu, J.; Rao, Y. Netrin Requires Focal Adhesion Kinase and Src Family Kinases for Axon Outgrowth and Attraction. Nat. Neurosci. 2004, 7, 1222-1232. [CrossRef]

63. Liu, T.J.; LaFortune, T.; Honda, T.; Ohmori, O.; Hatakeyama, S.; Meyer, T.; Jackson, D.; de Groot, J.; Yung, W.K.A. Inhibition of Both Focal Adhesion Kinase and Insulin-like Growth Factor-I Receptor Kinase Suppresses Glioma Proliferation in Vitro and in Vivo. Mol. Cancer Ther. 2007, 6, 1357-1367. [CrossRef] [PubMed]

64. Lim, S.T.; Chen, X.L.; Lim, Y.; Hanson, D.A.; Vo, T.T.; Howerton, K.; Larocque, N.; Fisher, S.J.; Schlaepfer, D.D.; Ilic, D. Nuclear FAK Promotes Cell Proliferation and Survival through FERM-Enhanced P53 Degradation. Mol. Cell 2008, 29, 9-22. [CrossRef] [PubMed]

65. Schaller, M.D. Cellular Functions of FAK Kinases: Insight into Molecular Mechanisms and Novel Functions. J. Cell Sci. 2010, 123, 1007-1013. [CrossRef] [PubMed] 
66. Xu, D.; Shen, W.; Guo, R.; Xue, Y.; Peng, W.; Sima, J.; Yang, J.; Sharov, A.; Srikantan, S.; Yang, J.; et al. Top3 $\beta$ Is an RNA Topoisomerase That Works with Fragile X Syndrome Protein to Promote Synapse Formation. Nat. Neurosci. 2013, 16, $1238-1247$. [CrossRef]

67. Goh, K.I.; Cusick, M.E.; Valle, D.; Childs, B.; Vidal, M.; Barabási, A.L. The Human Disease Network. Proc. Natl. Acad. Sci. USA 2007, 104, 8685-8690. [CrossRef]

68. Zotenko, E.; Mestre, J.; O'Leary, D.P.; Przytycka, T.M. Why Do Hubs in the Yeast Protein Interaction Network Tend to Be Essential: Reexamining the Connection between the Network Topology and Essentiality. PLoS Comput. Biol. 2008, 4, e1000140. [CrossRef]

69. Backx, L.; Marcelis, C.; Devriendt, K.; Vermeesch, J.; Van Esch, H.; Fryns, J.-P. Haploinsufficiency of the gene Quaking (QKI) is associated with the $6 \mathrm{q}$ terminal deletion syndrome. Am. J. Med. Genet. Part A 2010, 152A, 319-326. [CrossRef]

70. Lugtenberg, D.; Reijnders, M.R.F.; Fenckova, M.; Bijlsma, E.K.; Bernier, R.; Van Bon, B.W.M.; Smeets, E.; Silfhout, A.T.V.-V.; Bosch, D.; Eichler, E.E.; et al. De novo loss-of-function mutations in WAC cause a recognizable intellectual disability syndrome and learning deficits in Drosophila. Eur. J. Hum. Genet. 2016, 24, 1145-1153. [CrossRef]

71. Uehara, T.; Ishige, T.; Hattori, S.; Yoshihashi, H.; Funato, M.; Yamaguchi, Y.; Takenouchi, T.; Kosaki, K. Three patients with DeSanto-Shinawi syndrome: Further phenotypic delineation. Am. J. Med. Genet. Part A 2018, 176, 1335-1340. [CrossRef]

72. Hughes, J.J.; Alkhunaizi, E.; Kruszka, P.; Pyle, L.C.; Grange, D.K.; Berger, S.I.; Payne, K.K.; Masser-Frye, D.; Hu, T.; Christie, M.R.; et al. Loss-of-Function Variants in PPP1R12A: From Isolated Sex Reversal to Holoprosencephaly Spectrum and Urogenital Malformations. Am. J. Hum. Genet. 2020, 106, 121-128. [CrossRef]

73. Russell, S.A.; Bashaw, G.J. Axon guidance pathways and the control of gene expression. Dev. Dyn. 2017, 247, 571-580. [CrossRef]

74. Suter, T.A.C.S.; Jaworski, A. Cell migration and axon guidance at the border between central and peripheral nervous system. Science 2019, 365, eaaw8231. [CrossRef]

75. Chédotal, A. Roles of axon guidance molecules in neuronal wiring in the developing spinal cord. Nat. Rev. Neurosci. 2019, 20, 380-396. [CrossRef]

76. Engle, E.C. Human Genetic Disorders of Axon Guidance. Cold Spring Harb. Perspect. Biol. 2010, 2, a001784. [CrossRef]

77. Stoeckli, E.T. Understanding axon guidance: Are we nearly there yet? Development 2018, 145, dev151415. [CrossRef]

78. Takabatake, M.; Goshima, Y.; Sasaki, Y. Semaphorin-3A Promotes Degradation of Fragile X Mental Retardation Protein in Growth Cones via the Ubiquitin-Proteasome Pathway. Front. Neural Circuits 2020, 14, 1-9. [CrossRef]

79. O'Donnell, M.; Chance, R.K.; Bashaw, G.J. Axon Growth and Guidance: Receptor Regulation and Signal Transduction. Annu. Rev. Neurosci. 2009, 32, 383-412. [CrossRef]

80. Jourdy, Y.; Chatron, N.; Carage, M.L.; Fretigny, M.; Meunier, S.; Zawadzki, C.; Gay, V.; Negrier, C.; Sanlaville, D.; Vinciguerra, C. Study of six patients with completeF9deletion characterized by cytogenetic microarray: Role of theSOX3gene in intellectual disability. J. Thromb. Haemost. 2016, 14, 1988-1993. [CrossRef]

81. Kreis, P.; Barnier, J.-V. PAK signalling in neuronal physiology. Cell. Signal. 2009, 21, 384-393. [CrossRef]

82. Parker, N.H.; Donninger, H.; Birrer, M.J.; Leaner, V.D. p21-Activated Kinase 3 (PAK3) Is an AP-1 Regulated Gene Contributing to Actin Organisation and Migration of Transformed Fibroblasts. PLoS ONE 2013, 8, e66892. [CrossRef]

83. Peippo, M.; Koivisto, A.M.; Särkämö, T.; Sipponen, M.; Von Koskull, H.; Ylisaukko-Oja, T.; Rehnström, K.; Froyen, G.; Ignatius, J.; Järvelä, I. PAK3 related mental disability: Further characterization of the phenotype. Am. J. Med. Genet. Part A 2007, 143A, 2406-2416. [CrossRef]

84. Rejeb, I.; Saillour, Y.; Castelnau, L.; Julien, C.; Bienvenu, T.; Taga, P.; Chaabouni, H.; Chelly, J.; Jemaa, L.B.; Bahi-Buisson, N. A novel splice mutation in PAK3 gene underlying mental retardation with neuropsychiatric features. Eur. J. Hum. Genet. 2008, 16, 1358-1363. [CrossRef]

85. Qian, Y.; Wu, B.; Lu, Y.; Zhou, W.; Wang, S.; Wang, H. Novel PAK3 gene missense variant associated with two Chinese siblings with intellectual disability: A case report. BMC Med. Genet. 2020, 21, 31. [CrossRef]

86. Vicinanza, M.; Di Campli, A.; Polishchuk, E.; Santoro, M.; Di Tullio, G.; Godi, A.; Levtchenko, E.; De Leo, M.G.; Polishchuk, R.; Sandoval, L.; et al. OCRL Controls Trafficking through Early Endosomes via PtdIns4,5P 2-Dependent Regulation of Endosomal Actin. EMBO J. 2011, 30, 4970-4985. [CrossRef] [PubMed]

87. Hoopes, R.R.; Shrimpton, A.E.; Knohl, S.J.; Hueber, P.; Hoppe, B.; Matyus, J.; Simckes, A.; Tasic, V.; Toenshoff, B.; Suchy, S.F.; et al. Dent Disease with Mutations in OCRL1. Am. J. Hum. Genet. 2005, 76, 260-267. [CrossRef] [PubMed]

88. Böckenhauer, D.; Bökenkamp, A.; Nuutinen, M.; Unwin, R.; Van't Hoff, W.; Sirimanna, T.; Vrljicak, K.; Ludwig, M. Novel OCRL Mutations in Patients with Dent-2 Disease. J. Pediatr. Genet. 2012, 1, 15-23. [CrossRef] [PubMed]

89. Blackmore, M.G.; Moore, D.L.; Smith, R.P.; Goldberg, J.L.; Bixby, J.L.; Lemmon, V.P. High Content Screening of Cortical Neurons Identifies Novel Regulators of Axon Growth. Mol. Cell. Neurosci. 2010, 44, 43-54. [CrossRef]

90. Shahsavani, M.; Pronk, R.J.; Falk, R.; Lam, M.; Moslem, M.; Linker, S.B.; Salma, J.; Day, K.; Schuster, J.; Anderlid, B.M.; et al. An in Vitro Model of Lissencephaly: Expanding the Role of DCX during Neurogenesis. Mol. Psychiatry 2018, 23, 1674-1684. [CrossRef]

91. Robbins, J. KCNQ Potassium Channels: Physiology, Pathophysiology, and Pharmacology. Pharmacol. Ther. 2001, 90, 1-19. [CrossRef]

92. Surti, T.S.; Huang, L.; Jan, Y.N.; Jan, L.Y.; Cooper, E.C. Identification by Mass Spectrometry and Functional Characterization of Two Phosphorylation Sites of KCNQ2/KCNQ3 Channels. Proc. Natl. Acad. Sci. USA 2005, 102, 17828-17833. [CrossRef]

93. Miceli, F.; Striano, P.; Soldovieri, M.V.; Fontana, A.; Nardello, R.; Robbiano, A.; Bellini, G.; Elia, M.; Zara, F.; Taglialatela, M.; et al. A Novel KCNQ3 Mutation in Familial Epilepsy with Focal Seizures and Intellectual Disability. Epilepsia 2015, 56, e15-e20. [CrossRef] 
94. Sands, T.T.; Miceli, F.; Lesca, G.; Beck, A.E.; Sadleir, L.G.; Arrington, D.K.; Schönewolf-Greulich, B.; Moutton, S.; Lauritano, A.; Nappi, P.; et al. Autism and Developmental Disability Caused by KCNQ3 Gain-of-Function Variants. Ann. Neurol. 2019, 86, 181-192. [CrossRef]

95. Gu, Y.C.; Kortesmaa, J.; Tryggvason, K.; Persson, J.; Ekblom, P.; Jacobsen, S.E.; Ekblom, M. Laminin Isoform-Specific Promotion of Adhesion and Migration of Human Bone Marrow Progenitor Cells. Blood 2003, 101, 877-885. [CrossRef]

96. Najmabadi, H.; Hu, H.; Garshasbi, M.; Zemojtel, T.; Abedini, S.S.; Chen, W.; Hosseini, M.; Behjati, F.; Haas, S.; Jamali, P.; et al. Deep Sequencing Reveals 50 Novel Genes for Recessive Cognitive Disorders. Nature 2011, 478, 57-63. [CrossRef]

97. Aldinger, K.A.; Mosca, S.J.; Tétreault, M.; Dempsey, J.C.; Ishak, G.E.; Hartley, T.; Phelps, I.G.; Lamont, R.E.; O’Day, D.R.; Basel, D.; et al. Mutations in LAMA1 Cause Cerebellar Dysplasia and Cysts with and without Retinal Dystrophy. Am. J. Hum. Genet. 2014, 95, 227-234. [CrossRef]

98. Micalizzi, A.; Poretti, A.; Romani, M.; Ginevrino, M.; Mazza, T.; Aiello, C.; Zanni, G.; Baumgartner, B.; Borgatti, R.; Brockmann, K.; et al. Clinical, Neuroradiological and Molecular Characterization of Cerebellar Dysplasia with Cysts (Poretti-Boltshauser Syndrome). Eur. J. Hum. Genet. 2016, 24, 1262-1267. [CrossRef]

99. Corrêa, T.; Poswar, F.; Feltes, B.C.; Riegel, M. Candidate Genes Associated With Neurological Findings in a Patient With Trisomy 4p16.3 and Monosomy 5p15.2. Front. Genet. 2020, 11, 1-8. [CrossRef]

100. Corrêa, T.; Feltes, B.C.; Schinzel, A.; Riegel, M. Network-Based Analysis Using Chromosomal Microdeletion Syndromes as a Model. Am. J. Med. Genet. Part C Semin. Med. Genet. 2021, 1-12. [CrossRef] 